\title{
MENTORING OF CLASSROOM ACTION RESEARCH AND PUBLICATION OF SCIENTIFIC WORKS IN DEVELOPMENT OF SUSTAINABLE PROFESSION FOR ELEMENTARY SCHOOL TEACHERS
}

\author{
Wahyudi, Rokhmaniyah, Kartika Chrysti Suryandari
}

Universitas Sebelas Maret

wahyudi@fkip.uns.ac.id

\section{Article History}

accepted 30/09/2018

approved 12/10/2018

published 30/10/2018

\section{Keywords}

Mentoring, CAR, profession

\begin{abstract}
The aims of service are: (1) describe the implementation of workshop activities and mentoring the implementation of classroom action research (CAR) in sustainable professional development for elementary school teachers, (2) improve the understanding and skills of CAR in Sustainable Professional Development for elementary School Teachers. This Community Service activity uses the transfer of science and technology from universities to stakeholders which includes workshops and mentoring to elementary school teachers in Kebumen district in 2018. The data analysis used is descriptivequalitative which includes (1) data reduction, (2) data presentation, and (3) drawing conclusions or verification of data. The results of this activity are (1) workshop materials and mentoring include: (a) problem formulation techniques in CAR, (b) CAR proposal preparation techniques, (c) CAR implementation techniques, (d) CAR reporting techniques, (e) scientific publication writing techniques, and (f) teacher functional credit score promotion techniques. (2) Workshops and mentoring methods can improve CAR understanding and skills in sustainable professional development for elementary School Teachers
\end{abstract}

Social, Humanities, and Education Studies (SHEs): Conference Series https://jurnal.uns.ac.id/shes

p-ISSN 2620-9284 e-ISSN 2620-9292 


\section{PENDAHULUAN}

Masa depan masyarakat, bangsa, dan negara, sebagian besar ditentukan oleh guru. Oleh sebab itu, profesi guru perlu ditingkatkan dan dikembangkan secara terus menerus dan proporsional menurut jabatan fungsional guru. Selain itu, agar fungsi dan tugas yang melekat pada jabatan fungsional guru dilaksanakan sesuai dengan aturan yang berlaku, maka diperlukan penilaian kinerja guru yang menjamin terjadinya proses pembelajaran yang berkualitas di semua jenjang pendidikan. Pelaksanaan penilaian kinerja guru dimaksudkan bukan untuk menyulitkan guru, tetapi sebaliknya penilaian kinerja guru dilaksanakan untuk mewujudkan guru yang profesional, karena harkat dan martabat suatu profesi ditentukan oleh kualitas layanan profesi yang bermutu. Selain hal tersebut penilaian kinerja guru juga untuk menunjukkan secara tepat tentang kegiatan guru di dalam kelas, dan membantu mereka untuk meningkatkan pengetahuan serta keterampilannya. Dengan demikian diharapkan dapat memberikan kontribusi secara langsung pada peningkatan kualitas pembelajaran yang dilakukan, sekaligus membantu pengembangan karir guru sebagai tenaga profesional.

Untuk meyakinkan bahwa setiap guru adalah seorang profesional dalam bidangnya, maka penilaian kinerja guru harus dilakukan terhadap guru di semua satuan pendidikan formal yang diselenggarakan oleh pemerintah, pemerintah daerah, dan masyarakat. Guru dimaksud tidak terbatas pada guru yang bekerja di satuan pendidikan di bawah kewenangan Kementerian Pendidikan dan Kebudayaan, tetapi juga mencakup guru yang bekerja di satuan pendidikan di lingkungan Kementerian Agama. Hasil penilaian kinerja guru dan Evaluasi Diri digunakan untuk menyusun profil kinerja guru sebagai dasar penyusunan program Pengembangan Keprofesian Berkelanjutan. Hasil penilaian kinerja guru juga merupakan dasar penetapan perolehan angka kredit guru dari sub unsur pembelajaran/bimbingan dalam rangka pengembangan karir guru sebagaimana diamanatkan dalam Peraturan Menteri Negara Pendayagunaan Aparatur Negara dan Reformasi Birokrasi Nomor 16 Tahun 2009 tentang Jabatan Fungsional Guru dan Angka Kreditnya. Jika semua ini dapat dilaksanakan dengan baik dan obyektif, maka cita-cita pemerintah untuk menghasilkan "insan yang cerdas komprehensif dan berdaya saing tinggi" lebih cepat direalisasikan. Memperhatikan kondisi jabatan guru sebagai profesi dan kebijakan pemerintah dalam pengembangan profesi guru maka diperlukan pedoman pelaksanaan penilaian kinerja guru yang menjelaskan tentang apa, mengapa, kapan, bagaimana dan oleh siapa penilaian kinerja guru dilaksanakan. Penyusunan pedoman ini mengacu pada Peraturan Menteri Negara Pendayagunaan Aparatur Negara dan Reformasi Birokrasi No. 16 Tahun 2009 tentang Jabatan Fungsional Guru dan Angka Kreditnya sebagai acuan pelaksanaan penilaian kinerja guru di sekolah untuk mempermudah proses penilaian kinerja guru.

Hasil pengamatan dan studi pendahuluan di wilayah UPT Dinas Pendidikan Kecamatan Kebumen-Kabupaten Kebumen, menunjukkan bahwa sebagian besar guru, khususnya guru sekolah dasar, dalam pengembangan karier dan kepangkatan masih menghadapi kendala. Hal ini terlihat dari banyaknya guru yang mengalami kesulitan untuk naik jabatan dan pangkat, terutama pada golongan IV. Penyebab dari kendala tersebut terdiri dari beberapa hal, yaitu (1) guru kurang memahami tentang konsep Penelitian Tindakan Kelas (PTK), (2) guru kurang memahami tentang pelaksanaan Penelitian Tindakan Kelas (PTK), (3) guru kurang memahami tentang penyusunan laporan Penelitian Tindakan Kelas, (4) guru kurang memahami teknik pelaksanaan seminar hasil Penelitian Tindakan Kelas, (5) guru kurang memahami Teknik Penulisan Karya Tulis IImiah, dan (6) guru kurang memahami tentang penulisan jurnal ilmiah.

Berdasarkan kondisi rill di lapangan tersebut, maka Tim Pengabdian kepada Masyarakat merasa terpanggil untuk menindaklanjuti dan memecahkan permasalahan tersebut, yaitu untuk meningkatkan kompetensi guru sekolah dasar tentang pemahaman dan keterampilan 
melaksanakan Penelitian Tindakan Kelas, menyusun laporan Penelitian Tindakan Kelas, serta menyusun naskah artikel jurnal ilmiah dari hasil penelitian, dengan melaksanakan kegiatan "Pendampingan Penelitian Tindakan Kelas dan Penulisan Karya Tulis Imiah (KTI) untuk Pengembangan Keprofesian Berkelanjutan (PKB) bagi Guru Sekolah Dasar di Kecamatan Kebumen, Kabupaten Kebumen". Untuk itu, tujuan kegiatan Pengabdian kepada Masayarakat tersebut adalah: (1) mendeskripsikan pelaksanaan kegiatan workshop dan pendampingan pelaksanaan PTK dalam pengembangan keprofesian berkelanjutan bagi guru SD, (2) meningkatkan terhadap pemahaman dan Keterampilan PTK dalam Pengembangan Keprofesian Berkelanjutan bagi Guru Sekolah Dasar, (3) kendala dan solusi pelaksanaan kegiatan workshop dan pendampingan pelaksanaan PTK dalam pengembangan keprofesian berkelanjutan bagi guru SD.

\section{METODE}

Kegiatan Pengabdian kepada Masyarakat ini menggunakan desain Transfer ilmu pengetahuan dan teknologi dari perguruan tinggi kepada stake holder yang meliputi kegiatan: (a) Workshop, (b) Pelatihan dan pendampingan, dan (c) Seminar hasil PTK. Kegiatan pengabdian ini dilaksanakan di wilayah UPT Dinas Dikpora Kecamatan Kebumen - Kabupaten Kebumen. Kegiatan Pengabdian ini melibatkan 40 guru/kepala sekolah yang ada pada dua Gugus Kelompok Kerja Guru (KKG) di Kecamatan Kebumen, Kabupaten Kebumen, yaitu: (1) Gugus Rujakbeling dan (2) Gugus Banyumudal. Kegiatan Pengabdian ini dilaksanakan selama 4 bulan, yaitu mulai bulan Maret sampai dengan Juni 2018.

Kegiatan pengabdian ini menggunakan 3 jenis sumber data, yaitu (1) Guru SD, (2) kepala sekolah, dan (3) Dosen (Pengabdi. Dalam mengumpulkan data selama pelaksanaan kegiatan pengabdian berlangsung, digunakan teknik (a) observasi, (b) wawancara, (c) dokumen, (d) hasil unjuk kerja. Untuk menjaga keabsahan data atau validitas data, pengabdi menggunakan teknik triangulasi sumber data dan triangulasi teknik pengumpulan data yang melibatkan guru SD, kepala SD, dan teman sejawat (rekan dosen).

Analisis data yang digunakan dalam pengabdian ini adalah analisis data deskriptifkualitatif yang meliputi tiga alur kegiatan yang dilakukan secara bersamaan dan terus menerus selama dan setelah pengumpulan data yaitu (1) reduksi data, (2) penyajian data, dan (3) penarikan kesimpulan atau verifikasi data.

\section{Deskripsi kegiatan Pengabdian}

\section{HASIL DAN PEMBAHASAN}

Berdasarkan hasil pengamatan pada studi pendahuluan serta angket yang diperoleh dari guru di wilayah UPT Dinas Pendidikan Kecamatan Kebumen, menunjukkan bahwa sebagian besar guru, khususnya guru sekolah dasar, dalam pengembangan karier dan kepangkatan masih menghadapi kendala. Penyebab dari kendala tersebut terdiri dari beberapa hal, yaitu (1) guru kurang memahami tentang konsep Penelitian Tindakan Kelas (PTK), (2) guru kurang memahami tentang pelaksanaan Penelitian Tindakan Kelas (PTK), (3) guru kurang memahami tentang penyusunan laporan Penelitian Tindakan Kelas, (4) guru kurang memahami teknik pelaksanaan seminar hasil Penelitian Tindakan Kelas, (5) guru kurang memahami Teknik Penulisan Karya Tulis IImiah, dan (6) guru kurang memahami tentang penulisan jurnal ilmiah. Kendala tersebut akan diselesaikan melalui serangkaian kegiatan pengabdian kepada masyarakat.

Sebelum pelaksanaan program kerja pengabdian, Tim pengabdian kepada masyarakat mengawali dengan kegiatan sosialisasi dan diskusi tentang daftar kebutuhan dan permasalahan yang perlu mendapatkan penyelesaian. Tujuan kegiatan ini adalah untuk memberikan penyamaan persepsi terhadap kegiatan yang akan dilaksanakan yang meliputi (a) latar belakang kegiatan, (b) tujuan kegiatan, (c) skenario kegiatan, dan (d) indikator keberhasilan kegiatan. Kegiatan sosialisasi 
dilaksanakan pada tanggal 24 Maret 2018 di dua gugus Kelompok Kerja Guru (KKG), yaitu Gugus Banyumudal dan Gugus Rujakbeling di wilayah UPT Dinas Dikpora Kecamatan Kebumen yang diikuti oleh 60 guru dan kepala sekolah dasar. Untuk mengetahui permasalahan dan kebutuhan guru sekolah dasar tentang penulisan Penelitian Tindakan Kelas (PTK), maka pada kegiatan sosialisasi tersebut dibagikan angket kebutuhan stake holder tentang permasalahan penelitian tindakan kelas. Untuk mengetahui tingkat peminatan terhadap kegiatan workshop dan pendampingan, maka pada kegiatan ini juga dilakukan pendataan. Dari hasil pendataan peserta diperoleh data 60 guru sekolah dasar yang mengikuti kegiatan workshop dan pendampingan.

Berdasarkan hasil angket kebutuhan tentang permasalahan Penelitian Tindakan Kelas, maka diperoleh data materi yang dilaksanakan pada kegiatan workshop dan pendampingan sebagai berikut: (a) konsep Penelitian Tindakan Kelas, (b) penyusunan proposal PTK, (c) pendampingan pelaksanaan dan pelaporan PTK, (d) penyusunan laporan PTK, (e) seminar hasil pelaksanaan PTK, dan (f) penilaian angka kredit jabatan fungsional guru. Berdasarkan daftar kebutuhan guru sekolah dasar tentang pemahaman Penelitian Tindakan Kelas, maka dapat disusun struktur kurikulum kegiatan workshop dan pendampingan sebagai berikut:

\begin{tabular}{ll}
\multicolumn{2}{c}{ Tabel 1: Kurikulum Workshop dan Pendampingan PTK } \\
\hline Materi Kegiatan & $\begin{array}{l}\text { Jumlah } \\
\text { Jam }\end{array}$ \\
\hline Permasalahan dalam PTK & 2 \\
Proposal PTK & 2 \\
Pelaksanaan PTK & 2 \\
Pelaporan PTK & 2 \\
Penulisan Publikasi Ilmiah: Artikel IImiah & 2 \\
Penilaian Keprofesian Berkelanjutan:PAK & 2 \\
Pendampingan Pelaksanaan PTK & 6 \\
Pendampingan Pelaporan PTK & 6 \\
Pendampingan Seminar Hasil PTK & 6 \\
Pendampingan Penulisan Artikel Ilmiah & 2 \\
Jumlah & 32 \\
\hline
\end{tabular}

Kegiatan workshop dan pendampingan PTK ini secara keseluruhan dilaksanakan selama 4 bulan (8 pertemuan), yaitu mulai bulan Maret 2018 sampai dengan bulan Juni 2018, yang diikuti oleh 40 guru sekolah dasar di Gugus Banyumudal dan Gugus Rujakbeling UPT Dinas Dikpora Kecamatan Kebumen Kabupaten Kebumen. Kegiatan workshop dan pendampingan dilaksanakan setiap hari Sabtu, mulai pukul 11.00 - 15.00 WIB, setelah selesai jam sekolah, sehingga kegiatan ini tidak mengganggu kegiatan dinas guru di sekolah.

Kegiatan workshop dilaksanakan selama 3 pertemuan (12 jam) dengan menggunakan metode ceramah, tanya jawab, diskusi, dan pemberian tugas. Adapun materi workshop meliputi (a) teknik rumusan pemasalahan dalam PTK, (b) teknik penyusunan proposal PTK, (c) teknik pelaksanaan PTK, (d) teknik pelaporan PTK, (e) teknik penulisan publikasi ilmiah, dan (f) teknik penilaian angka kredit kenaikan jabatan fungsional guru. Sedangkan kegiatan pendampingan dilaksanakan setelah kegiatan workshop, dengan menggunakan metode pendampingan dan bimbingan individu. Metode ini digunakan untuk memberikan pelayanan bimbingan sesuai dengan kecepatan, kemampuan, dan permasalahan yang dihadapi oleh masing-masing guru. Kegiatan pendampingan dilaksanakan selama 5 pertemuan (20 jam). Pada kegiatan pendampingan ini melibatkan 3 dosen pendamping. Adapun materi pendampingan meliputi (a) pelaksanaan PTK di sekolah, (b) pelaporan PTK, (c) seminar hasil PTK, dan penulisan artikel ilmiah. 


\section{Peningkatan Keterampilan PTK dalam Pengembangan Keprofesian Berkelanjutan melalui Workshop dan Pendampingan bagi Guru SD.}

Setelah kegiatan Workshop dan Pendampingan dilaksanakan sesuai dengan rencana kegiatan, maka selanjutnya dilakukan evaluasi dan refleksi terhadap kegiatan tersebut. Kegiatan evaluasi dan refleksi bertujuan untuk mengetahui perubahan pemahaman guru SD terhadap keterampilan PTK dalam Pengembangan Keprofesian Berkelanjutan. Selain itu, kegiatan evaluasi dan refleksi juga digunakan untuk menemukan kendala yang dihadapi pada kegiatan Workshop dan Pendampingan. Selanjutnya, dari kendala yang ditemukan akan dicarikan solusi untuk mengatasi kendala tersebut. Berdasarkan hasil pengumpulan data tentang pelaksanaan kegiatan Workshop dan Pendampingan, maka diperoleh data sebagai berikut.

Tabel: 2 Hasil Workshop dan Pendampingan PTK (40 Guru SD)

\begin{tabular}{lll}
\hline Materi Workshop dan Pendampingan & $\begin{array}{l}\text { Rerata } \\
\text { Skor Awal }\end{array}$ & $\begin{array}{l}\text { Rerata } \\
\text { Skor Akhir }\end{array}$ \\
\hline Kegiatan Pelatihan/Diklat & 1,95 & 3,23 \\
Permasalahan dalam PTK & 1,41 & 3,73 \\
Penyusunan Proposal PTK & 1,49 & 3,80 \\
Pelaksanaan PTK & 1,35 & 3,63 \\
Pelaporan PTK & 1,13 & 3,64 \\
Penulisan Publikasi IImiah: Artikel IImiah & 1,45 & 3,25 \\
Penilaian Keprofesian Berkelanjutan & 1,23 & 3,68 \\
PAK Kenaikan Jabatan Fungsional Guru & 1,43 & 3,80 \\
Rerata Skor Akhir & $\mathbf{1 , 4 7}$ & $\mathbf{3 , 5 7}$ \\
\hline
\end{tabular}

Keterangan: 1 = Kurang; 2 = Cukup; 3 = Baik; 4 = Baik sekali

Dari data pada tabel 2 tersebut di atas dihasilkan peningkatan pemahaman dan keterampilan PTK dalam Pengembangan Keprofesian Berkelanjutan. Peningkatan pemahaman terjadi pada setiap aspek dari fokus penelitian, yaitu: (a) Kegiatan Pelatihan/Diklat/Sosialisasi dari rata-rata 1,95 menjadi 3,23 (Baik); (b) Permasalahan dalam PTK, dari rata-rata 1,41 menjadi 3,73 (Baik); (c) Penyusunan Proposal PTK, dari rata-rata 1,49 menjadi 3,80 (Baik); (d) Pelaksanaan PTK, dari rata-rata 1,53 menjadi 3,63 (Baik); (e) Pelaporan PTK, dari rata-rata 1,13 menjadi 3,64 (Baik); (f) Penulisan Publikasi Ilmiah: Artikel Ilmiah, dari rata-rata 1,45 menjadi 3,25 (Baik); (g) Penilaian Keprofesian Berkelanjutan, dari rata-rata 1,23 menjadi 3,68 (Baik); (h) Penilaian Angka Kredit Kenaikan Jabatan Fungsional Guru, dari rata-rata 1,47 menadi 3,57 (Baik). Dari kedelapan aspek yang diukur, maka dapat disimpulkan adanya peningkatan yang signifikan pada pemahaman dan Keterampilan PTK dalam Pengembangan Keprofesian Berkelanjutan bagi Guru SD. Hal ini terbukti dari rata-rata pemahaman dan keterampilan PTK terjadi peningkatan dari 1,47 (Kurang) menjadi 3,57 (Baik).

\section{Kendala dan Solusi Pelaksanaan Workshop dan Pendampingan PTK dalam Pengembangan Keprofesian Berkelanjutan bagi Guru SD.}

Kegiatan Workshop dan Pendampingan PTK dalam Pengembangan Keprofesian Berkelanjutan bagi Guru SD dilaksanakan sesuai dengan perencanaan yang disusun, namun demikian dalam pelaksanaannya ditemukan beberaa kendala, yaitu: (a) beberapa guru kurang fokus dalam mengikuti Workshop dan Pendampingan, karena padatnya kegiatan di sekolah, (b) beberapa guru kurang menguasai TIK, (c) beberapa guru kurang aktif melaksanakan tugas Workshop dan Pendampingan, (d) beberapa guru masih memerlukan pendampingan yang lebih intensif, karena kecepatan berfiirnya berbeda. Adapun alternatif solusinya adalah: (a) kegiatan Workshop dan Pendampingan dilaksanakan pada awal semester atau hari libur 
sekolah, (b) guru perlu bantuan/ pendampingan orang yang menguasai TIK, (c) Waktu pelaksanaan tugas diperpanjang, (d) perlu pengelompokan guru berdasarkan kecapatan berfikir/usia.

Selain kendala pada pelaksanaan kegiatan Workshop dan Pendampingan, maka ditemukan juga kendala dalam penguasaan materi Workshop dan Pendampingan, yaitu:

a. Kendala pada Kegiatan Pelatihan/Diklat/Sosialisasi adalah: (1) kurang mendapatkan sosialisasi tentang Pengembangan Keprofesian Berkelanjutan; (2) guru kurang berusaha mencari tahu tentang Pengembangan Keprofesian Berkelanjutan;

b. Kendala pada Permasalahan dalam PTK adalah: (1) guru kurang terbiasa melaksanakan perbaikan pembelajaran, (2) guru kurang terbiasa menganalisis masalah pembelajaran;

c. Kendala dalam Penyusunan Proposal PTK adalah: (1) guru merasa sulit menentukan judul penelitian, (2) guru kesulitan menyusun instrumen penelitian;

d. Kendala pada Pelaksanaan PTK adalah: (1) guru kurang menyiapkan perangkat penelitian, (2) guru kurang lengkap dalam Pengumpulan data penelitian;

e. Kendala pada Pelaporan PTK adalah: (1) guru kurang menguasai sistematika laporan penelitian, (2) tidak semua guru menguasai TIK;

f. Kendala pada Penulisan Publikasi Ilmiah adalah: (1) guru belum terbiasa melaksanakan seminar hasil penelitian, (2) guru belum menguasai teknik menyusun artikel jurnal ilmiah, (3) guru belum pernah melaksanakan publikasi ilmiah;

g. Kendala pada Penilaian Keprofesian Berkelanjutan adalah: (1) guru kurang memahami jenis-jenis Penilaian Keprofesian Berkelanjutan;

h. Kendala tentang Pemahaman penilaian Angka kredit adalah: (1) guru kurang memahami teknik penilaian angka kredit kenaikan jabatan, (2) guru kurang lengkap dalam pengumpulan berkas administrasi penilaian Angka Kredit untuk kenaikan jabatan.

Adapun alternatif solusinya adalah:

a. Solusi untuk Kegiatan Pelatihan/Diklat/Sosialisasi adalah: (1) perlu sosialisasi tentang Pengembangan Keprofesian Berkelanjutan; (2) perlu bimbingan mencari literatur tentang Pengembangan Keprofesian Berkelanjutan;

b. Solusi untuk Permasalahan dalam PTK adalah: (1) diberi pemahaman dan latihan tentang perbaikan pembelajaran, (2) diberi pemahaman dan latihan menganalisis masalah pembelajaran;

c. Solusi untuk Penyusunan Proposal PTK adalah: (1) pembimbingan dan pendampingan menentukan judul penelitian, (2) pembimbingan dan pendampingan menyusun instrumen penelitian;

d. Solusi untuk Pelaksanaan PTK adalah: (1) guru lebih menyiapkan perangkat penelitian, (2) guru lebih teliti dan lengkap dalam Pengumpulan data penelitian;

e. Solusi untuk Pelaporan PTK adalah: (1) Pemahamana tentang sistematika laporan penelitian, (2) peningkatan penguasaan TIK;

f. Solusi untuk Penulisan Publikasi IImiah adalah: (1) pelatihan dan pendampingan seminar hasil penelitian, (2) pelatihan dan pendampingan teknik menyusun artikel jurnal ilmiah, (3) pelatihan dan pendampingan publikasi ilmiah;

g. Solusi untuk Penilaian Keprofesian Berkelanjutan adalah: (1) sosialisasi Penilaian Keprofesian Berkelanjutan;

h. Solusi untuk Pemahaman penilaian Angka kredit adalah: (1) sosialisasi teknik penilaian angka kredit kenaikan jabatan, (2) sosialisasi dan pembimbingan pengumpulan berkas administrasi penilaian Angka Kredit untuk kenaikan jabatan. 


\section{SIMPULAN}

berikut:

Berdasarkan hasil analisis dan pembahasan, maka dapat disimpulkan sebagai

1. Kegiatan workshop dilaksanakan selama 3 pertemuan (12 jam) dengan materi workshop meliputi (a) teknik rumusan pemasalahan dalam PTK, (b) teknik penyusunan proposal PTK, (c) teknik pelaksanaan PTK, (d) teknik pelaporan PTK, (e) teknik penulisan publikasi ilmiah, dan (f) teknik penilaian angka kredit kenaikan jabatan fungsional guru. Sedangkan kegiatan pendampingan dilaksanakan setelah kegiatan workshop, dilaksanakan selama 5 pertemuan (20 jam). Pada kegiatan pendampingan ini melibatkan 3 dosen pendamping. Adapun materi pendampingan meliputi (a) pelaksanaan PTK di sekolah, (b) pelaporan PTK, (c) seminar hasil PTK, dan penulisan artikel ilmiah.

2. Metode workshop dan pendampingan dapat meningkatkan secara signifikan terhadap pemahaman dan Keterampilan PTK dalam Pengembangan Keprofesian Berkelanjutan bagi Guru Sekolah Dasar. Hal ini terbukti dari rata-rata pemahaman dan keterampilan PTK terjadi peningkatan dari 1,47 (Kurang) menjadi 3,57 (Baik).

3. Kendala pada pelaksanaan kegiatan workshop dan pendampingan adalah: (a) beberapa guru kurang fokus dalam mengikuti kegiatan, (b) beberapa guru kurang menguasai TIK, (c) beberapa guru kurang aktif dalam kegiatan, (d) beberapa guru masih memerlukan pendampingan yang lebih intensif. Adapun alternatif solusinya adalah: (a) kegiatan Workshop dan Pendampingan dilaksanakan pada awal semeste, (b) guru perlu bantuan/ pendampingan orang yang menguasai TIK, (c) waktu pelaksanaan tugas diperpanjang, (d) perlu pengelompokan guru berdasarkan kecapatan berfikir/usia.

\section{DAFTAR PUSTAKA}

Kemendikbud. (2013). Pengelolaan Pengembangan Keprofesian Berkelanjutan (Buku 1). Jakarta: Kemendikbud

Kemendikbud. (2013). Pedoman Pelaksanaan Penilaian Kinerja Guru (PK Guru) (Buku 2). Jakarta: Kemendikbud.

Kemendikbud. (2013). Pedoman Kegiatan Pengembangan Keprofesian Berkelanjutan(PKB) (Buku 4). Jakarta: Kemendikbud.

Kemendikbud. (2013). Pedoman Penilaian Kegiatan Pengembangan Keprofesian Berkelanjutan (PKB) (Buku 5). Jakarta: Kemendikbud.

Peraturan Bersama Mendiknas dan Kepala BKN No: 03/V/PB/2010 dan No: 14 Tahun 2010 tentang Petunjuk Pelaksanaan Jabatan Fungsional Guru dan Angka Kreditnya.

Permendiknas No. 35 Tahun 2010 tentang Petunjuk Teknis Pelaksanaan Jabatan Fungsional Guru dan Angka Kreditnya.

Permendiknas No. 38 Tahun 2010 tentang Penyesuaian Jabatan Fungsional Guru.

Permenneg PAN \& RB No. 16 Tahun 2009 tentang Jabatan Fungsional Guru dan Angka Kreditnya.

Rohendi Rohidi, T. (1992). Analisis Data Kualitatif: Terjemehan: Qualitative Data Analysis (Mathew B. Miles dan A. Michael Huberman). Jakarta: Penerbit UI Press.

Undang-Undang Nomor 20 Tahun 2003 tentang Sistem Pendidikan Nasional. Jakarta: Sinar Grafika

Undang-Undang Nomor 14 Tahun 2005 tentang Guru dan Dosen. Jakarta: Sinar Grafika. 